\title{
Shopping Centres Maintenance Management Performance: A Case Study
}

Joaquim Moreira

Sonae Sierra Portugal

Manuel Pereira Lopes

Assistant Professor CIDEM-ISEP

Polytechnic Institute of Porto

Portugal

Paulo Ávila

Coordinator Professor CIDEM-ISEP

Polytechnic Institute of Porto

Portugal
A Shopping Centre (SC) is a "shop open to the public", installed in a building, which include parking, several shops, technical, management, and shopping arcade. In the current economic climate, the maintenance of complex buildings, like shopping centres, is performed under a tight budget context, and is essentially based on systems conditions. A maintenance model, to be effective, requires that maintenance service performance, covering the different building systems and components, is measured. This paper presents a methodology to measure the performance of SCs maintenance management through two major performance indicators: the Building Performance Indicator (BPI); and the Maintenance Efficiency Indicator (MEI). The results of its implementation to seven shopping centres, in Portugal, show that the general condition of the facilities is good (overall BPI= 86,45\%) but the low MEI values $(<0,37)$ indicates that insufficient resources are allocated to maintenance activities and this can compromise the future condition of the facilities.

Keywords: key performance indicators, facilities management, Building Performance Indicator, maintenance management, Maintenance Efficiency Indicator, shopping centres, Portugal.

\section{INTRODUCTION}

A Shopping Centre (SC) is a "shop open to the public", installed in a building, that can be classified as small, medium or large. In Portugal, they are modern buildings of trade/services type, with broad areas, featuring a shopping mall, with areas partially divided. Generally, the SC are multi-floor buildings, which include parking, several shops, technical, management, and shopping arcade. A commercial shopping centre is essentially composed of large stores (anchors), medium and small size (satellites), conventional restaurants and fast food, and movie theatres. Communication between floors is assured by escalators and elevators, for consumers, and corridors that allow technicians to carry out the stores replenishments and waste transport, without interfering with public areas of the centre, for the shopkeepers and the rear of stores. These corridors also serve in emergency situations as escape routes.

To ensure the functioning of the centres, facilities, such as, power systems (switchboards, switchgear and cables) HVAC Systems (circulator pumps, chillers, fans, air handling units, cooling towers, etc.), supply systems for drinking water and wastewater (circulator pumps, distribution networks and collectors, chemical treatments), fire detection and firefighting (automatic fire detection and fire-fighting network reels, a network of sprinklers, fire detectors, fire panels, etc.), surveillance and communication systems (closed circuit

Received: October 2015, Accepted: November 2015

Correspondence to: Dr Manuel Lopes

Instituto Superior de Engenharia do Porto,

Porto, Portugal

mpl@isep.ipp.pt

doi:10.5937/fmet1504328M

(C) Instituto Superior de Engenharia do Porto. All rights reserved television, telephones, etc.), lifting and handling systems (elevators, escalators and passenger conveyors), are implemented in the technical areas.

The operation and management of a shopping centre is vital to its success and is an intensive process, which is usually conducted by a multifunctional team, to cover areas of management, marketing, landscaping, maintenance, security and so on.

One of the most important management functions is to optimize the return on investment, focusing on strategies that minimize operating costs, including property management, management of operations and facilities.

Maintenance plays a significant role in the property management. Maintenance is a necessary part of the SC business. The maintenance management systems should ensure that the SC operates efficiently in order to preserve and improve the owner's investment. Maintenance in the SC business is more than just repair equipment, and/or systems. It needs to assure the future of the asset (the SC), through a maintenance program that includes activities necessary to maintain the physical infrastructure and the support services.

This kind of management is important to ensure the quality and effectiveness of maintenance of facilities that usually vary in their size and type of construction.

An adequate facility management can result in a support aligned with the organization's mission, the anticipation of future facility requirements, the ability to foresee results of current management decisions, and the reducing of the operational inefficiencies [1]. Furthermore, organizational performance is closely related to a facility's performance [2].

In SC there is a set of facilities available to the public and shopkeepers like parking, WC's, signage, 
HVAC, elevators, escalators, public telephones and ATMs which provide comfort and convenience that attract consumers and retailers to visit it. Therefore, it is important for the management of SC to maintain high levels of satisfaction for both shopkeepers and consumers, and that this is done efficiently. In the life cycle of a SC, maintenance takes a leading role in building high performance and requires that in the early stages of design, maintenance management is taken into account. The performance of commercial centres and their components depends to a large extent on the continuous periodic maintenance, based on a wellstructured maintenance program. While more and more there is a need to reduce operating costs, management should also ensure that the facilities are built and maintained efficiently, without compromising security.

\section{FUNDAMENTALS}

The literature review illustrates the need for Key Performance Indicators that allow analysts to assess the performance of buildings and that also can be used in facilities management and maintenance.

A set of KPIs must be identified and followed over a period of time so that it can be compared against a baseline in order to scrutinise improvements or deterioration [3].

Current measurement practices must emphasize aspects like business, business goals, and job satisfaction. The traditional metrics relating to financial and space aspects express the performance level of the building but do not indicate the contribution made to the organization's strategic results [4].

Approaches like benchmarking, the balanced scorecard, post occupancy evaluation, and measurement through metrics of key performance indicators (KPIs), are included in major facility performance measurement practices [5].

Such indicators can support the monitoring of performance and provide a basis for additional indicators in the assessment of maintenance and quality of services in this area. However, it appears that there is a dilemma in the choice and development of assessment methods resulting from the need of a compromise between the complexity of research and the quality of results. Most researchers in this area follow the idea that an adequate assessment can be achieved by minimizing the cost of resources and time requirements. Some approaches use statistical techniques to reduce the scope of the survey [6].

Another approach, which is employed in projects requiring rehabilitation or renovation of buildings, focuses on the diagnosis of deterioration and employs statistical tools, quantitative and analytical, which are used by specialists from different disciplines involved in the assessment [7].

Another evaluation model used in the renovation of military sites [3] is based on three functions:

1. Physical parameters,

2. Functional parameters such as geometry, security and system compatibility, and

3. Location of facilities and peripheral infrastructures.
Mailvaganam and Alexander [8] developed an easy to use multi-stage repair activities processing model, which is based on an assessment of the building.

Shen and Lo [9] developed a system of cumulative points, which ranks buildings according to the assessment of priorities for renewal. This methodology analyses three criteria:

1. the physical condition of the building;

2. the importance of the building function and

3. the influence exerted by its users.

Each building is given a score for each criterion. The specific scale for each criterion depends on the relative importance defined by the evaluator. For example, the scale related to the physical condition of the building can vary between 1 and 10, whereas the scale used to record the importance of the building function can vary between 1 and 5 . This means that the weight of the physical condition is twice the building function. The final score is the sum of the scores for each criterion. This method is suitable for setting priorities, but cannot be used for an economic evaluation of maintenance costs.

Spedding et al. [10] [11], from the University of the West of England, developed a method called MultiAttribute System. This method is based on a comprehensive study of different methods for the determination of maintenance priorities. The study involved a number of projects implemented by local authorities in England and Wales. Six criteria were chosen to determine the priorities for maintenance, as follows:

1. indispensability of the building, or the lack thereof;

2. physical condition of the building;

3. importance of the facility's use;

4. resultant effect on the users;

5. resultant effects on structures and

6. effects on service provision.

The relative weight of each criterion $C_{i}$ is $W_{i}$, and for each job $j$, is given a score $\left(S_{j 1}, S_{j 2}, \ldots, S_{j n}\right)$. The priority index (or total score), $S_{j}$, can be calculated using Equation 1:

$$
S_{j}=S_{j 1} * W_{1}+S_{j 2} * W_{2}+\ldots+S_{j n} * W_{n}
$$

The process of criteria ranking and weighting can vary among different users. The scores for the criteria above were collected and used to rank projects on a relative scale, in descending order.

Caccavelli and Gender [12] developed a methodology to summarize the current condition of a building and estimate the cost of various works, as well as the need to renew, with regard to energy conservation. The methodology is composed of 50 elements, between one and six element types, and four codes per type. Each element is classified according to the following category code:

1. in good condition;

2. slight degradation

3. medium degradation;

4. poor condition (requires replacement).

Allehaux and Tessier [13] applied quality criteria to determine the functional obsolescence of electromechanical systems in office buildings. 
Pullen et al. [14] defined seven KPIs to assess the maintenance service in Australian hospitals. Most of them were business oriented. However, the performance of the building was not included in any of them.

McDougall and Hinks [15] indicated that the economic and financial indicators are neither sufficient nor satisfactory for the analysis of performance management of facilities once the performance aspects of building are not integrated in these indicators.

A joint research conducted by the Commonwealth Scientific and Industrial Research Organisation (CSIRO) and Queensland University of Technology have developed a prototype model to facilitate decision making on the sale, maintenance, and review the building portfolio. The model includes two main indicators: Property Standard Index (PSI), and the Hold/Sell Index [16]. The PSI is based on a number of factors related to the physical condition of the building, its age, and construction standards for new residential buildings [17]. The model was tested and deployed in a large number of houses owned and maintained by the Queensland Department of Housing. The PSI provides an indicator that shows the potential impact of resource allocation on the general condition of the building, and economic feasibility of corrective maintenance [18].

This study describes the implementation to seven shopping centres, in Portugal, of a methodology for evaluating the performance of a $\mathrm{SC}$ as a whole. The methodology will give us an indication of the condition of the building's components and systems, as well as a key performance indicator to monitor the performance of the buildings and consequently the efficiency of the maintenance teams. The main goals are:

1. Present the implementation results of a KPI through a systematic approach, which enables the assessment of maintenance efficiency in shopping centres. The assessment will be based on the performance of building components by a uniform criteria.

2. Establish a measurement system for the assessment of the buildings. This system will reflect a comprehensive view of building performance.

3. Provide systematic indicators to prioritize maintenance activities.

The model used in this study is an adaptation of Shohet et al [19][20] approach used in public hospitals in Israel. Given the similarity between the types of buildings (hospitals and shopping centres), it is also our aim to show that this methodology is valid for shopping centres.

\section{EVALUATION OF SHOPPING CENTERS MAINTENANCE PERFORMANCE}

The performance model includes two KPIs, BPI and $M E I$, as follows:

BPI - The Building Performance Indicator (BPI) monitors the physical condition and fitness for use of the building and its various systems, based on quantitative criteria. Each of the building systems (structural elements, exterior envelope, interior finishes, electrical systems, HVAC systems, water supply and wastewater systems, detection and firefighting, surveillance and communication, and systems to lift and transport) is rated on a performance scale of $(0-100)$, expressing their physical and functional condition $\left(P_{k}\right)$.

The classification system for each $P_{k}$ is expressed on a scale of $0-100$, and is given by Equation 2 [19]:

$$
P_{k}=C_{k}^{*} W(C)_{k}+F_{k}^{*} W(F)_{k}+P M_{k}^{*} W(P M)_{k}
$$

The classification comprises three aspects concerning the maintenance of the facilities:

1. actual condition of the system $-C_{k}$

2. failures affecting the service provided by the system $-F_{k}$

3. actual preventive activities carried out on the system to maintain acceptable service level $-P M_{k}$.

Where:

$W(C)_{k}=$ weight of component condition of system $k$

$W(F)_{k}=$ weight of failures in system $k$

$W(P M)_{k}=$ weight of preventive maintenance for system $k$

For every system $k$, the sum $W(C)_{k}+W(F)_{k}+W(P M)_{k}$ $=1$.

The value of $C_{k}$ is obtained based on a scale of 100 points, where 100 expresses the total performance score, 60 in damage and 40 and 20, failure and poor performance, respectively.

Preventive maintenance $P M_{k}$ is evaluated based on the existence of a preventive maintenance plan and its implementation frequency.

Frequency of failure $F_{k}$ is assessed on a scale between 100 - no failures in 12 months, and 20 - occur frequently (e.g., occurring 12 times in the last 12 months).

The combination of these three elements represents the performance score of the entire system, $P_{k}$.

The weight of internal components of each building system is divided into two categories: (1) physical performance and frequency of failures of the specific building system, representing the service level, and (2) execution of preventive maintenance and periodical inspections of the specific building system, reflecting the labour and material resources [19].

The weight of each building system, the $W_{k}$, is determined by Equation 3 [19]:

$$
W k=\frac{\sum_{j=1}^{m}\left(R_{k j}+M_{k j}+C_{k j}\right)}{\sum_{k=1}^{n} \sum_{j=1}^{m}\left(R_{k j}+M_{k j}+C_{k j}\right)}
$$

Where:

$n=$ Number of building systems

$k=$ Index of building system

$W_{k}=$ Weigth of the $k t h$ building system (structure, exterior envelope, etc.)

$j=$ Index of component in system $j$ (e.g. pumps, fans in HVAC system)

$m=$ Number of components in building system

$R_{k j}=$ Replacement cost of component $j$ in system $k$ at the end of its predicted life cycle. It is assumed that a component is replaced only if the remaining service life of the building is greater than 0,5 of its life cycle.

$M_{k j}=$ Annual maintenance costs of component $j$ in system $k$ 
$C_{n j}=$ Reinstatement value of component $j$ in the $k t h$ building system

BPI can be calculated using Equation 4 [19]:

$$
B P I=\sum_{k=1}^{n} P_{k}^{*} W_{k}
$$

Where:

$B P I=$ Building performance Indicator (0-100)

$P_{k}=$ Performance level for system $k$ (on a scale of 0 to 100$)$

$W_{k}=$ Weight of system $k$ in the BPI, as determined by Equation 3.

The value of $B P I$ reflects the performance level of the building: when $B P I>80$, the condition and performance are good or reasonable, $70<B P I \leq 80$ indicates the building condition is such that some systems are in marginal condition (some preventive maintenance actions should be taken), $60<B P I \leq 70$ reflects deterioration of the building (some corrective maintenance actions should be taken), and $B P I \leq 60$ means that the building is deteriorated. Global $B P I$ is obtained by adding the performance values of each system [19].

The weights distribution for the SC context are presented in Table 1.

Table 1. Weight distribution (\%) in each building system (adapted from [19] to the SC context)

\begin{tabular}{|l|c|c|}
\hline \multicolumn{1}{|c|}{ Building System } & $\begin{array}{c}\text { Weight of } \\
\text { physical } \\
\text { performance and } \\
\text { failures }\end{array}$ & $\begin{array}{c}\text { Weight of } \\
\text { periodical } \\
\text { maintenance }\end{array}$ \\
\hline Structural elements & 90 & 10 \\
\hline Interior finishing & 70 & 30 \\
\hline External envelope & 75 & 25 \\
\hline $\begin{array}{l}\text { Fire detection and fire } \\
\text { fighting }\end{array}$ & 75 & 25 \\
\hline $\begin{array}{l}\text { Communication and } \\
\text { surveillance }\end{array}$ & 50 & 50 \\
\hline Lifting and handling & 60 & 40 \\
\hline Electrical & 50 & 50 \\
\hline HVAC & 50 & 50 \\
\hline Water and waste water & 75 & 25 \\
\hline
\end{tabular}

The $90 \%$ of the weight assigned to the physical performance and failures of structural elements, for example, reflects a low need for maintenance of the structural elements compared with the impact of failures in these elements.

The weight of each building system is calculated according to the ratio of the cost of the life cycle of each system and the building's life cycle costs. Consequently, the structural elements have the biggest weight, followed by the external envelope, and the interior finishing. On the other hand, in this study, it was found that the maintenance costs and the allocation of human resources, at each facility, is mainly $(90 \%)$ dedicated to the maintenance of electromechanical systems. In this context, the importance of these factors in BPI, is not noticeable due to the lower weight that each of these systems represent in total building systems. To overcome this visibility limitation, the use of the following two partial indicators, $B P I_{S E}$ and $B P I_{E E}$, are proposed:

- $B P I_{S E}$ (Building Performance Indicator for Structural Elements) - includes the structural elements, the external envelope, and the interior finishing.

- $B P I_{E E}$ (Building Performance Indicator for Electromechanical Elements) - includes the electrical systems, HVAC systems, water supply and wastewater systems, detection and firefighting, surveillance and communication, and systems to lift and transport.

MEI - The Maintenance Efficiency Indicator (MEI) monitors the performance of maintenance operations. This indicator observes the maintenance inputs, as calculated based on the annual maintenance expenditure $(A M E)$, with respect to the physical and performance state of the building as expressed by the building performance indicator $(B P I)$. It represents a quantitative indication of the spending efficiency of the available resources, taken into account the building's age and occupancy level [20].

The annual maintenance expenditure $(A M E)$, measured in $€$ per square meter of built area, expresses the amount of resources spent on maintenance activities during the fiscal year, and combines the cost of internal resources, outsourcing, contractors, materials and spare parts, excluding the cost of cleaning, security and energy, but without any reference to the features of the building and its use. All activities designed to prevent a failure or deterioration of building components, to repair a failed component, or to replace a component as it reached the end of its useful life is included in $A M E$. This indicator can be used to normalize the maintenance expenditures from one year to another, as to compare the costs for maintenance between different facilities. An accurate calculation of the $A M E$ requires all expenses that are not directly related to the maintenance should be excluded from total expenditure. This means that spending on renovation and modernization are not taken into account. Annual maintenance costs were calculated based on the building components maintenance cost, and the replacement cost of components at the end of their life cycle. An analysis of annual maintenance costs revealed a great deal of fluctuation from year to year, due to the accumulation of a high number of replacements during several specific years [20].

The facility coefficient, $F A C(y)$, determines projected maintenance and assesses actual maintenance efficiency. This indicator can be used by facility managers to plan the allocation of resources for the overall maintenance of the entire building. It can also be used for a short and long term planning to determine the life cycle cost of a given building in a given year of its life. It is calculated based on the following parameters: 
the age of the building, its physical environment (marine or in-land), mid-level occupation and configuration of systems and components. In this paper, the marine environment is defined as a range of $1 \mathrm{~km}$ along the coast. Elsewhere outside this range is set to inland environment. As a result, coefficient changes from one year to the next.

The values presented in Table 2, represent the predicted values of the facility coefficient, in five-year intervals over the useful life of a building, for each of the six combinations between the category of the environment (two-point scale) and the level of occupation (three-point scale).

Table 2. $F A C(y)$ - facility coefficient (adapted from [19] to the SC context)

\begin{tabular}{|l|l|l|l|l|l|l|}
\hline \multirow{2}{*}{$\begin{array}{c}\text { Building } \\
\text { age }\end{array}$} & \multicolumn{5}{|c|}{ In-land } & \multicolumn{3}{c|}{ Marine } \\
\cline { 2 - 7 } & \multicolumn{7}{|c|}{ Low } & Normal & High & Low & Normal & High \\
\hline 5 & 0,37 & 0,42 & 0,51 & 0,4 & 0,45 & 0,54 \\
\hline 10 & 0,45 & 0,53 & 0,66 & 0,47 & 0,56 & 0,68 \\
\hline 15 & 0,83 & 0,86 & 1,03 & 0,85 & 0,88 & 1,06 \\
\hline 20 & 1,14 & 1,2 & 1,49 & 1,21 & 1,26 & 1,55 \\
\hline 25 & 1,07 & 1,2 & 1,36 & 1,16 & 1,29 & 1,45 \\
\hline 30 & 1,03 & 1,08 & 1,11 & 1,07 & 1,12 & 1,15 \\
\hline 35 & 1,27 & 1,35 & 1,6 & 1,26 & 1,34 & 1,58 \\
\hline 40 & 1,52 & 1,53 & 1,79 & 1,54 & 1,55 & 1,8 \\
\hline 45 & 1,19 & 1,4 & 1,5 & 1,25 & 1,46 & 1,57 \\
\hline 50 & 0,95 & 1,3 & 1,21 & 0,99 & 1,34 & 1,26 \\
\hline 55 & 1,19 & 1,23 & 1,29 & 1,22 & 1,26 & 1,32 \\
\hline 60 & 1,16 & 1,23 & 1,6 & 1,2 & 1,28 & 1,64 \\
\hline 65 & 0,7 & 0,84 & 1,05 & 0,74 & 0,88 & 1,09 \\
\hline 70 & 0,41 & 0,42 & 0,51 & 0,45 & 0,46 & 0,55 \\
\hline 75 & 0,4 & 0,39 & 0,5 & 0,43 & 0,43 & 0,53 \\
\hline
\end{tabular}

The maintenance efficiency indicator $(M E I)$ is given by Eq. 5 [20]:

$$
M E I=\frac{A M E}{B P I \times F A C_{\mathrm{y}}}
$$

The calculated $M E I$ may take values equal or greater than zero.

The significance of the MEI values in hospital buildings, and by similarity in shopping centres, is as follows [15]:

- $M E I<0,37$, represent a state in which the budgetary investment is low, or the utilization efficiency of maintenance resources is high, or both.

- $0,37<M E I<0,52$ represent the ideal situation for a maintenance department, indicating adequate utilization of maintenance resources.

- $M E I>0,52$ indicates high inputs relative to the actual performance. Such high values may express high maintenance expenditure, or low building performance, or a combination of both extreme situations.

This indicator provides facility managers, valuable information, in terms of strategic decisions, on the effectiveness of maintenance implementation. It can also be used as a decision criterion for the allocation of maintenance resources in cases where the available resources are limited, such as the shopping centres.

As for the BPI indicator, to give the adequate visibility to the individual systems performance, two different set of systems to calculate $M E I$ are proposed:

- $M E I_{S E}$ - The Maintenance Efficiency Indicator for the set of structural systems.

- $M E I_{E E}$ - The Maintenance Efficiency Indicator for the set of electromechanical systems.

$$
M E I_{E E}=\frac{A M E_{E E}}{B P I_{E E} \times F A C_{\mathrm{y}}}
$$

$M E I_{E E}$ - The Maintenance Efficiency Indicator for electromechanical systems.

$A M E_{E E}$ - The Annual Maintenance Expenditure for electromechanical systems.

$B P I_{E E}$ - The Building Performance Indicator for electromechanical systems.

\section{RESULTS}

The results of the implementation of this methodology to the seven shopping centres of this study, are presented in following tables (3 and 4). The detailed data and results can be found in [21].

\begin{tabular}{|c|c|c|c|c|c|c|c|}
\hline $\begin{array}{l}\text { Building } \\
\text { System }\end{array}$ & 1 & 2 & 3 & 4 & 5 & 6 & 7 \\
\hline $\begin{array}{l}\text { Structural } \\
\text { elements }\end{array}$ & 0,31 & 0,38 & 0,31 & 0,26 & 0,24 & 0,4 & 0,29 \\
\hline $\begin{array}{l}\text { Interior } \\
\text { finishing } \\
\end{array}$ & 0,11 & 0,14 & 0,08 & 0,14 & 0,22 & 0,1 & 0,09 \\
\hline $\begin{array}{l}\text { External } \\
\text { envelope }\end{array}$ & 0,16 & 0,13 & 0,15 & 0,14 & 0,13 & 0,18 & 0,14 \\
\hline $\begin{array}{l}\text { Fire } \\
\text { detection and } \\
\text { fire fighting }\end{array}$ & 0,04 & 0,03 & 0,08 & 0,06 & 0,05 & 0,06 & 0,09 \\
\hline $\begin{array}{l}\text { Communica- } \\
\text { tion and } \\
\text { surveillance }\end{array}$ & 0,1 & 0,09 & 0,11 & 0,13 & 0,08 & 0,05 & 0,11 \\
\hline $\begin{array}{l}\text { Lifting and } \\
\text { handling }\end{array}$ & 0,01 & 0,02 & 0,03 & 0,02 & 0,03 & 0,02 & 0,03 \\
\hline Electrical & 0,07 & 0,03 & 0,06 & 0,05 & 0,07 & 0,02 & 0,05 \\
\hline HVAC & 0,01 & 0,01 & 0,02 & 0,02 & 0,01 & 0,01 & 0,02 \\
\hline $\begin{array}{l}\text { Water and } \\
\text { waste water }\end{array}$ & 0,04 & 0,04 & 0,02 & 0,03 & 0,02 & 0,06 & 0,04 \\
\hline$B P I_{S E}$ & 0,86 & 0,88 & 0,85 & 0,85 & 0,86 & 0,89 & 0,86 \\
\hline$B P I_{E E}$ & 0,86 & 0,87 & 0,86 & 0,86 & 0,86 & 0,90 & 0,86 \\
\hline$B P I$ & 0,86 & 0,88 & 0,85 & 0,85 & 0,86 & 0,89 & 0,86 \\
\hline
\end{tabular}

Table 3. BPI results for the seven shopping centres

All facilities have a $B P I$ greater than $80 \%$, which means that they are in good condition, with an overall performance of $86.5 \%$ (Table 3 ). 
The Table 3 results, demonstrate that structural elements weight hides the actual value of the performance of electromechanical systems. This additional visibility is very important due to the importance of Electromechanical Elements in SC buildings. For example, in building 6 there is a significant difference between the $B P I_{S E}$ and $B P I_{E E}$, although the $B P I$ performance is very similar to the other facilities, which may be due to an inadequacy of the electromechanical systems to building needs.

Table 4. MEI results for the seven shopping centres

\begin{tabular}{|l|c|c|c|c|c|c|c|}
\hline & 1 & 2 & 3 & 4 & 5 & 6 & 7 \\
\hline$A M E_{E E}$ & 0,86 & 0,88 & 0,85 & 0,85 & 0,86 & 0,89 & 0,86 \\
\hline$B P I_{E E}$ & 0,86 & 0,87 & 0,86 & 0,86 & 0,86 & 0,90 & 0,86 \\
\hline$F A C(y)$ & 1,03 & 0,51 & 1,45 & 1,40 & 0,70 & 0,66 & 0,83 \\
\hline$M E I_{E E}$ & 0,10 & 0,18 & 0,05 & 0,06 & 0,11 & 0,17 & 0,30 \\
\hline
\end{tabular}

The results presented in Table 4 show values for $M E I<0,37$, which represents both, a state of low budgetary investment, as could be confirmed in the field during the data collection process, where it was found that maintenance teams are reduced in number. On the other hand, it might be said that the maintenance policies are suitable and efficient, both in terms of outsourcing and internal maintenance resources, even though, in a different perspective, this can compromise the future condition of the SC facilities.

\section{CONCLUSIONS}

Assessing the state of buildings is highly important to the success of any maintenance and rehabilitation program through a management indicator. The evaluation methodology presented in this paper aims to provide an objective and systematic method for the analysis and assessment of buildings before the execution of maintenance activities and rehabilitation. The methodology uses scales for assessing the performance of building components. The condition of the building is assessed by the BPI.

The method allows the determination of priorities based on the performance of the entire building $(B P I)$, and performance of each building system. The BPI represents a KPI for the performance assessment of buildings and can be extended to generate KPIs for the evaluation of resources and efficiency of maintenance operations.

Despite the advantages, the methodology, however, requires a thorough understanding of the scales used for each building component. The methodology also requires a thorough field research to avoid errors in critical components, such as structural components or fire protection system.

This methodology generates quality and quantity indicators of management for the following purposes:

1. Evaluate the general condition of systems in a particular building.

2. Assess the condition of a system of a particular building during the assessment. For example, BPI allows the identification of components with a consistent tendency to be in poor condition.

3. Provide a comparative measure for the definition of priority in the allocation of resources (financial, labour and materials).

4. Allow for benchmarking between multiple buildings.

To overcome an identified visibility limitation of $B P I$ indicator, two partial indicators were proposed: $B P I_{S E}$ and $B P I_{E E}$, for the set of structural systems and the set of electromechanical systems, respectively.

The Maintenance Efficiency Indicator (MEI) monitors the performance of maintenance operations. It represents a quantitative indication of the spending efficiency of the available resources, taken into account the building's age and occupancy level. Following the proposed split of BPI in two sets of systems, an identical approach is proposed for $M E I$.

In this case study, this methodology was used to measure the maintenance management performance of Shopping Centres, through two major performance indicators: the Building Performance Indicator (BPI); and the Maintenance Efficiency Indicator $(M E I)$. The results of its implementation to seven shopping centres, in Portugal, show that the general condition of the facilities is good (overall $B P I=86,5 \%$ ) but the low $M E I$ values $(<0,37)$ indicates that insufficient resources are allocated to maintenance activities and this can compromise the future condition of the SC facilities.

In future work, it is recommended to extend the application of this methodology to other buildings, such as service buildings, such as, banks or office towers, and even football stadiums, to validate its generality. It is also important to confirm the interest to have partial BPI and $M E I$ indicators for the set of structural systems and the set of electromechanical systems, in other facilities.

Taking into account environmental concerns, the current economic conditions and financial constraints, the determination of an energy performance indicator of the building, not on the basis of consumption (electrical and/or thermal), but based on the contribution made by the efficiency of maintenance, should be also considered in future work.

\section{REFERENCES}

[1] Cable, J.H. and Davis, J.S.: Key Performance Indicators for Federal Facilities Portfolios, Federal Facilities Council Technical Report 147, National Academies Press, Washington, DC, 2004.

[2] Preiser, W.F.E. and Vischer, J.C.: Assessing Building Performance, Elsevier, Oxford, 2005.

[3] Brackertz, N.: Relating physical and service performance in local government community facilities, Facilities, Vol. 24 Nos 7/8, pp. 280-91, 2006.

[4] Lavy, S., Garcia, J. A., \& Dixit, M. K.: Establishment of KPIs for facility performance measurement: review of literature. Facilities, 28(9/10), 440-464, 2010.

[5] Uzarski, D.R. and Burley, L.A.: Assessing building conditions by the use of condition indexes. 
Proceedings of the Specialty Conference on Infrastructure condition Assessment: Art Science Pratice, ASCE, New York, 365-74, 1997.

[6] Baba, A.: A proposal for a general system for making diagnosis of reinforced concrete building. Processing of the International Symposium on Property Management and Modernization, Edit by Quah Lee Kiang, 7-9 March, 1990, Singapore, 78998, 1990.

[7] Building renovation decision support model. Proceedings of the 5th international conference on computing in civil and building engineering, ANAHEIM, Ca, USA, 1547-54.

[8] Mailvaganam, N.P. and Alexander, T.: Procedural sequence in the Repair of Buildings. Journal of Thermal Envelope and Building Science, 23(4), 349-61, 2000.

[9] Shen Q.P. and Lo K.K.: Priority Setting Maintenance Management - An Analytic Approach, The Hong Kong Polytechnic University, 1999.

[10] Spedding, A., Holmes, R. and Shen, Q.P.: Priority planned maintenance in county authorities. International Conference on Planned Maintenance, Rehabilitation, Reliability and Quality Assurance, Cambridge, UK, 6-7 April,172-8, 1995.

[11] Shen Q.P. and Spedding, A.: Priority setting in planned maintenance - practical issues in using the multi-attribute approach. Building Research and Information, 26(3), 169-80, 1998.

[12] Caccavelli, D. and Genre, J.L.: Diagnosis of the degradation state of building and cost evaluation of induced refurbishment works. Energy-andBuildings, 31(2), 159-65, 2000.

[13] Allehaux, D. and Tessier, P.: Evaluation of the functional obsolescence of building services in European office buildings. Energy-and-Buildings, 34(2), 127-33, 2002.

[14] Pullen, S., Attkinson, D. and Tucker, S.: Determining economical maintenance intervals. International Symposium on Facilities Management and Maintenance, Brisbane, Australia, 265-71, 2000.

[15] McDougall, G. and Hinks, J.: Exploring the issues for performance assessment in Facilities Management. Proceedings of the International Symposium on Facilities Management and Maintenance, Brisbane, Australia, 251-9, 2000.

[16] O'shea, J., Then, D.S. and Tucker, S.N.: The development of a property standard index Queensland Department of Housing. Proceedings of the CIBW70 International Symposium on
Facilities Management and Maintenance, Brisbane, Australia, 49-55, 2000.

[17] Johnston, D.R., McFallan, S.L. and Tilly, P.A.: Implementation of a property standard index. Facilities 20(3/4), 136-44, 2002.

[18] Tucker, S.N., Johnston, D.R. and McFallan, S.L.: The Property Standard Index: How well has it performed? Proceedings of the CIB W-70 2002 Global Symposium, Glasgow, September, 497-506, 2002.

[19] Shohet, I. M., Lavy-Leibovich, S., \& Bar-On, D.: Integrated maintenance monitoring of hospital buildings. Construction Management \& Economics, 21(2), 219-228, 2003.

[20] Lavy, S., \& Shohet, I. M.: Integrated healthcare facilities maintenance management model: case studies. Facilities, 27(3/4), 107-119. 2009.

[21] Moreira, J, and Lopes, M. P.: MODELO DE GESTÃO DE INSTALAÇÕES EM CENTROS COMERCIAI. Master thesis, Instituto Superior de Engenharia do Porto, 2011.

\section{ПЕРФОРМАНСЕ УПРАВЉАЬА ОДРЖАВАњЕМ ТРЖНИХ ЦЕНТАРА: СТУДИЈА СЛУЧАЈА}

\section{Ж. Мореира, М. П. Лопеш, П. Авила}

Тржни центар је „продавница отворена за јавност“, смештена у згради, у којој се налази паркинг, неколико радионица, техничка и служба управљања, и продајни простор. У садашњој економској клими, одржавање сложених објеката, какви су тржни центри, обавља се са ограниченим финансијским средствима и у основи се заснива на стању система. Један ефективни модел одржавања захтева да се врши мерење перформанси службе одржавања која покрива различите системе зграде и њених компонената. Овај рад приказује методологију мерења перформансе управљања одржавањем тржног центра преко два основна показатеља перформансе: показатељ перформансе објекта и показатељ ефикасности одржавања. Резултати примене наведене методологије у седам тржних центара у Португалији показују да је опште стање објеката добро (за први индикатор укупно износи $86,45 \%$ ), али нешто нижа вредност за други индикатор (<0,37\%) показује да се за одржавање додељују недовољни ресурси и да то може да угрози стање објеката у будућности. 